\title{
Market Competition, Earnings Management, and Persistence in Accounting Profitability Around the World
}

\section{Citation}

Healy, Paul M., George Serafeim, Suraj Srinivasan, and Gwen Yu. "Market Competition, Earnings Management, and Persistence in Accounting Profitability Around the World." Review of Accounting Studies (forthcoming).

\section{Published Version}

http://link.springer.com/article/10.1007/s11142-014-9277-8

\section{Permanent link}

http://nrs.harvard.edu/urn-3:HUL.InstRepos:13426864

\section{Terms of Use}

This article was downloaded from Harvard University's DASH repository, and is made available under the terms and conditions applicable to Open Access Policy Articles, as set forth at http:// nrs.harvard.edu/urn-3:HUL.InstRepos:dash.current.terms-of-use\#OAP

\section{Share Your Story}

The Harvard community has made this article openly available.

Please share how this access benefits you. Submit a story.

\section{Accessibility}




\title{
Market competition, earnings management, and persistence in accounting profitability around the world
}

\section{January 2014}

\begin{abstract}
We examine how cross-country differences in product, capital, and labor market competition, as well as earnings management affect mean reversion in accounting return on assets. Using a sample of 48,465 unique firms from 49 countries, we find that accounting returns mean revert faster in countries where there is more product and capital market competition, as predicted by economic theory. Country differences in labor market competition and earnings management are also related to mean reversion in accounting returns - but the relation varies with firm performance. Country labor competition increases mean reversion when unexpected returns are positive but slows it when unexpected returns are negative. Accounting returns in countries with higher earnings management mean revert more slowly for profitable firms and more rapidly for loss firms. Thus earnings management incentives to slow or speed up mean reversion in accounting returns are accentuated in countries where there is a high propensity for earnings management. Overall, these findings suggest that country factors explain mean reversion in accounting returns and are therefore relevant for firm valuation.
\end{abstract}

Keywords: Earnings management; Mean reversion; Product market competition; labor market competition; Return on assets. JEL Classifications: G15; F37; M41. 


\section{Introduction}

This paper tests whether mean reversion in corporate profitability varies systematically across countries. We hypothesize that the degree of competition in a country's product, capital, and labor markets and cross-country differences in earnings management affect mean reversion in corporate accounting rates of return.

One of the strong propositions of economic theory is that, in competitive economies, new entrants compete away economic rents (Stigler 1961). As a result, in a general equilibrium framework, firms with either superior or subnormal profits are expected to converge toward the mean (e.g., Arrow and Debreu, 1954). This proposition has motivated a large literature in management to search for factors that enable firms to enjoy sustainable competitive advantages and mitigate economic pressure for mean reversion (Porter 1980, 1985; Lippman and Rumelt 1982; Hoskisson et al. 2000; Wiggins and Rueffli 2002).

Understanding whether and how corporate profitability mean reverts across countries matters for valuation. A firm's economic value can be measured by its ability to generate book returns in excess of its cost of capital (Ohlson 1995). Thus the speed of mean reversion in excess accounting return on assets (ROA), the measure of corporate profitability used throughout the paper, is critical for estimating forecast horizons and terminal values in valuation (Healy et al. 2000, Penman 2006). Understanding how forecast horizons and terminal values vary across countries is therefore likely to allow investors and financial intermediaries to make more accurate valuation estimates.

There are two reasons to expect that country-level factors are important drivers of mean reversion in accounting rates of return. First, legislation in product and factor (i.e., 
capital and labor) markets that affect the level of competition is typically determined at the country-level (La Porta et al. 1998, Doidge et al. 2007). Regulations such as government subsidies, import tariffs, labor regulations, and financial liberalization directly affect whether firms can sustain abnormal profits. Second, the institutions that govern business activities and affect entrepreneurs' incentives to innovate and enter new markets are typically established at the country level (Caves 1989, Porter 1990, Khanna and Palepu 1997, North 1990). In this paper, we examine three measures of the strength of competition expected to influence mean reversion in profitability: competition in product, capital, and labor markets.

Since we use accounting rates of return, mean reversion is also likely to be affected by earnings management. Extensive prior research has shown that earnings management varies systematically across countries, reflecting country differences in reporting standards and enforcement (Ball et al. 2000, Leuz et al. 2003). We hypothesize that capital market pressure induces managers of firms with abnormally high accounting rates of return to use reporting discretion to slow mean reversion. In contrast, managers of firms with abnormally low accounting returns have capital market pressures to use their reporting judgment to accelerate mean reversion and demonstrate a turnaround in their firm's performance. These earnings management effects are expected to be stronger for firms that operate in countries with higher earnings management.

To test our predictions, we use a sample of 48,465 unique firms from 49 countries in the period from 1997 to 2008 . The intertemporal dynamics of corporate accounting rates of return are analyzed using a partial adjustment model (Fama and French 2000) that examines changes in returns as a function of prior years' unexpected returns. Our 
analysis uses firm-year-level data to examine how country measures of product and factor market competition and earnings management affect mean reversion in ROA. Firm-level observations allow us to control for firm and industry characteristics that prior studies have shown to affect the speed of mean reversion in earnings.

The results of multivariate tests reveal predictable variation in mean reversion in accounting profitability across countries. Mean reversion is faster in countries with more competitive product and capital markets. Holding firm and industry characteristics constant, an inter-quartile increase in home country product (capital market) competition increases mean reversion for a representative firm by approximately $10.9 \%(3.4 \%)$. In contrast, mean reversion is slower in countries with more competitive labor markets. However, this finding is attributable to loss-making firms; for profit making firms, an inter-quartile increase in the labor markets is accompanied by a $2.8 \%$ increase in accounting profitability mean reversion.

One explanation of the anomalous results for loss firms is that, in countries with efficient labor markets, loss-making firms face greater difficulty in retaining and recruiting talent, making a turnaround more difficult and mitigating mean reversion. The labor market competition variable may also capture other institutional characteristics that differentially affect the loss and profit making firms in the economy. In our empirical tests, we attempt to control for such effects (e.g., corruption), but unobservable country factors that are correlated with labor market competition may drive the effect on mean reversion.

Finally, our tests show a nonlinear relation between mean reversion in accounting returns and cross-country variation in earnings management. Profitable firms in countries 
with a higher earnings management propensity have slower rates of mean reversion, consistent with managers using reporting judgment to slow mean reversion. An interquartile increase in the level of home country earnings management is associated with a 3.3\% lower mean reversion. In contrast, loss-making firms in countries with a high earnings management propensity have faster rates of mean reversion, suggesting that their managers used reporting discretion to boost earnings. For these firms, an interquartile increase in the level of home country earnings management increases mean reversion by $5.5 \%$ relative to profit-making firms.

In summary, our findings complement research on mean reversion in profitability that focuses on firm (Nissim and Penman 2001) and industry-level factors (Lev 1983, Fairfield et al. 2009). We document that country-level factors such as product, labor, and capital market competition and earnings management are associated with the rate of mean reversion of corporate accounting returns and are therefore relevant inputs to forecasts of firms' future performance. While our results are consistent with economic theory, we recognize that it is difficult to attribute causality, especially given various alternative channels that drive competitive forces in an economy (e.g., government regulation). Unobserved country characteristics correlated with competition may drive the mean reversion results.

The remainder of the paper proceeds as follows. We develop our hypotheses in Section II and describe the research design in Section III. We discuss the data in Section IV and the results in Section V. We present additional analyses Section VI and conclude in Section VII. 


\section{Hypothesis development and prior literature}

Economic theory predicts that firms' profitability rates mean revert and converge to an economy-wide mean. Although firms seek to sustain any competitive advantage and resist mean reversion (Schumpeter 1942, Porter 1985), they are typically subject to the economic laws of competition (Aghion et al. 2001, Aghion 2002). Firms that generate superior performance face competition from new entrants, reducing future rents. Similarly, under-performing firms either survive by improving profitability or fail, further leading to profitability mean reversion.

A long stream of accounting literature finds evidence of mean reversion in accounting rates of return. Beaver (1970) documented that firms with high ROEs experience a decrease in ROE in subsequent periods, whereas firms with low ROEs experience a subsequent increase, albeit at a slower rate. Penman (1991) found that, although ROA is mean reverting, it also includes a persistent component that allows firms with high ROA to continue to outperform in the future.

The rate at which accounting returns mean revert is of broad interest because equity values are based on sustainable profits (Freeman et al. 1982). The Ohlson (1995) valuation framework links equity values to profitability persistence and shows how equity values are a linear combination of book value and current profits weighted by persistence. Typically, more persistent profits generate a larger valuation effect, whereas purely transitory profits have little impact on a firm's stock price. The persistence of corporate profitability, therefore, has a direct effect on equity valuation.

Numerous subsequent studies have sought to understand drivers of the time-series properties of corporate profitability (see Kothari 2001 for a review). These studies find 
that mean reversion in accounting returns is a function of both firm- and industry-level characteristics. Firm-level determinants include firm size (Lev 1983), future investment opportunities (Nissim and Penman 2001), and accounting measurement errors (Penman and Zhang 2002). Cheng (2005) shows that persistence for large firms can be explained in part by product differentiation and market shares (measured using R\&D and advertising intensity), suggesting that a firm's industry structure affects the persistence of its performance (Waring 1996). Consistent with this hypothesis, Lev (1983) finds that industry barriers-to-entry, product type, and degree of capital intensity partially explain the persistence of ROAs. Fama and French (2000) show that that rate of mean reversion is greater for extreme accounting rates of returns.

Our study contributes to this research by examining how country-level factors affect the persistence of accounting rates of return. We predict that the rate of mean reversion in accounting returns varies across countries and that this variation is systematically related to competition in the country's factor and product markets and the extent of earnings management.

\section{Country product market and factor competition}

Product market effects: Porter (1980) describes how barriers to entry (e.g., scale economies, first mover advantage, legal barriers, and access to distribution) affect product market competition. Profitable firms that face low barriers to entry are likely to see their profits eroded by competitors, leading to mean reversion in profitability. Similarly, firms with underperforming business segments are likely to exit the market in search for higher returns, also leading to faster mean reversion of performance. Therefore 
we predict that product market competition will increase the speed of mean reversion in accounting returns.

There are two reasons why product market competition might vary across countries. First, many countries impose trade barriers and tariffs as direct entry barriers to their domestic markets. Such obstacles can lead to differences across countries in competition from foreign firms. Second, the effectiveness of regulations that promote product market competition varies across countries. Our empirical measure of product market competition thus includes both the existence of legislation that promotes openness in product markets (e.g., tariffs and regulatory restrictions on foreign or newly created firms) as well as the extent of domestic product market openness (e.g., ease of doing business). The appendix includes a list of variables included in our study.

Capital market effects: An efficient capital market is expected to lead to faster mean reversion in accounting returns by facilitating the allocation of resources to their highest value in use. Such a market provides financially constrained entrepreneurs with access to funds required to compete against profitable incumbents, leading to increased product market competition and faster mean reversion (Wurgler 2000). At the same time, efficient capital markets discourage firms from investing in negative valued projects (Morck et al. 2005) and facilitate the restructuring or closure of under-performing firms, also accelerating mean reversion.

We examine various country-level measures of the efficiency of the domestic capital market and related institutions in performing this allocation role. Following prior studies, we measure the efficiency of a country's capital market using the size and liquidity of its domestic equity and bond markets and other qualitative measures of 
investor protection and shareholder rights (La Porta et al. 1998). Our measure also reflects measures of financial institutions' transparency and effective regulation and the availability of alternative capital sources, such as venture capital.

Labor market effects: Labor is an important factor input to a firm's production function. In well-functioning labor markets, new firms that seek to challenge successful incumbents can attract labor at a competitive price. In contrast, if the labor market is effectively closed, it will be difficult for new firms to attract talent, enabling profitable incumbents to sustain their performance. Consequently, in more competitive labor markets, accounting returns are likely to mean revert more rapidly. However, more competitive labor markets may also make it difficult for under-performing firms to attract and retain talent, exacerbating their under-performance and leading to slower mean reversion. ${ }^{1}$

Competition in the labor market is expected to vary by country because domestic labor laws influence employment and compensation contracts (Botero et al. 2004). Rules governing employment security and unemployment legislation vary systematically across countries, and compensation contracts are influenced by the bargaining power of domestic labor unions (Freeman 1988, Siegel and Larson 2009). ${ }^{2}$ In our empirical tests, we use measures of labor market regulation (e.g., unemployment and immigration laws) and other qualitative assessments of employment flexibility to gauge competition in the labor market. The above three competition factors generate our first hypothesis:

\footnotetext{
${ }^{1}$ Of course forces of competition can force persistent loss-making firms to quickly exit the market. However, note that the competition variable of interest here is the competition in the labor market (and not competition in markets that force firms to easily exit, e.g., the takeover market).

${ }^{2}$ Siegel and Larson (2009) show that the extent to which the pay-for-performance relationship holds in different countries is related to the bargaining power of domestic labor unions.
} 
H1: Greater competition in a country's product, capital, and labor markets generates faster mean reversion in accounting returns.

\section{Country earnings management}

Mean reversion in accounting rates of return is also likely to be affected by earnings management. Extensive research has documented earnings management and its causes (see Dechow and Skinner (2000) and Healy and Wahlen (1999) for a summary). Ball et al. (2000) argue that the level of earnings management varies systematically across countries based on differences in country reporting standards and enforcement. Studies find evidence in support of country differences in earnings management and in the enforcement of accounting standards (Leuz et al. 2003).

We hypothesize that capital market pressures induce managers of firms with positive abnormal accounting returns to use reporting discretion to slow any effect of mean reversion. In contrast, managers of firms with losses and abnormally low returns face capital market pressures to use their reporting judgment to demonstrate a turnaround in their firm's performance, accelerating mean reversion. These earnings management effects are expected to be stronger for firms that operate in countries with higher earnings management propensity.

H2: Accounting returns in countries with higher earnings management mean revert more slowly for profitable firms and more rapidly for loss firms.

\section{Research design}

We test the effect of institutional characteristics on performance persistence using the partial adjustment model proposed by Fama and French (2000):

$$
\mathrm{ROA}_{\mathrm{i}, t+1}-\mathrm{ROA}_{\mathrm{i}, \mathrm{t}}=\alpha+\beta\left[\mathrm{ROA}_{\mathrm{i}, \mathrm{t}}-\mathrm{E}\left(\mathrm{ROA}_{\mathrm{i}, \mathrm{t}}\right)\right]+\gamma\left[\mathrm{ROA}_{\mathrm{i}, \mathrm{t}}-\mathrm{ROA}_{\mathrm{i}, \mathrm{t}-1}\right]+\varepsilon_{\mathrm{i}, t+1} .
$$


ROA is operating income divided by total assets. We use operating income because we want to capture the intertemporal dynamics of the ability of a company to deliver performance from its operations and because our hypotheses focus on how institutional characteristics affect a firm's ability to sustain economic performance. Moreover, by using operating income, we avoid introducing noise in the estimates because of differences across countries in the accounting treatment of non-operating and special items. $^{3}$

ROAs are predicted to mean revert to an expected value, E(ROA), which is estimated each year using the following cross-sectional model (see Fama and French 2000):

$\mathrm{ROA}_{\mathrm{i}, \mathrm{t}}=\lambda_{0}+\lambda_{1} \mathrm{D} / \mathrm{BV}_{\mathrm{i}, \mathrm{t}}+\lambda_{2} \mathrm{DD}_{\mathrm{i}, \mathrm{t}}+\lambda_{3} \mathrm{SIZE}_{\mathrm{i}, \mathrm{t}}+\lambda_{4} \mathrm{LEV}_{\mathrm{i} . \mathrm{t}}+\lambda_{5} \mathrm{MB}_{\mathrm{i}, \mathrm{t}}+$ Fixed effects $+\varepsilon_{\mathrm{i}, \mathrm{t}}(2)$

where $\mathrm{D} / \mathrm{BV}$ is cash dividends over book value of equity; $\mathrm{DD}_{\mathrm{i}, \mathrm{t}}$ is an indicator variable that takes a value of one for dividend payers and zero otherwise; SIZE is the natural logarithm of sales; LEV is total debt over total assets; and MB is the market-to-book ratio. We include both industry and country indicators to control for unobservable changes in earnings that are not captured by the variables included in equation (2). This model is widely used in prior literature (Fama and French 2006) and assumes that the predictors of ROA in the current period are sufficient to predict current expected ROA. In

\footnotetext{
${ }^{3}$ When we use net income excluding extraordinary items, we find very similar results, and when we use net income including extraordinary items, we find similar results but the statistical significance is reduced.

${ }^{4}$ Our specification differs from the standard partial adjustment model used in the capital structure literature (Flannery and Rangan 2006). Unlike standard adjustment models, which use current variables to measure the level of the future targets (e.g., expected target ROA), we use current observables to measure the level of the current expected value (e.g., expected current ROA). An important assumption for our model is that expected ROA does not include abnormal profits. If this assumption does not hold, leading to measurement errors that are correlated with our country-level competition variables, the model estimates are likely to be biased. In our main analyses, we include specific country-level controls that can drive such measurement errors (e.g., properties of reported earnings). In addition, we test the sensitivity of our results using a onestage estimation methodology (see Table V).
} 
other words, no residual autocorrelation exists in the explanatory variables in equation (2). We estimate the coefficients using Fama Macbeth regressions. ${ }^{5}$

The estimated $\beta$ coefficient in equation (1) is the level of mean reversion in profitability and our main variable of interest. If ROA exhibits mean reversion, we expect $\beta$ to be negative. This can be seen by rearranging the model in equation (1) as following:

$$
\mathrm{ROA}_{i, t+1}=\alpha+(1+\beta) \mathrm{ROA}_{i, t}+(-\beta) E\left(\mathrm{ROA}_{i, t}\right)+\gamma\left[\mathrm{ROA}_{\mathrm{i}, \mathrm{t}}-\mathrm{ROA}_{\mathrm{i}, \mathrm{t}-1}\right]+\varepsilon_{\mathrm{i}, \mathrm{t}+1} .
$$

Assuming that no residual autocorrelation exists in changes in $\operatorname{ROA}(\gamma=0)$, the coefficient on the second term $(1+\beta)$ can be interpreted as the persistence of earnings examined in prior literature (Francis et al. 2004). Also, the second and third terms of equation (3) imply that future ROA is a weighted average of current realized ROA and current expected ROA. If $\beta$ equals zero, current realized ROA fully persists in the next period. Alternatively, if $\beta$ takes the value of -1 , next period's ROA is determined solely by expected ROA, and there is zero persistence. Finally, the fourth term $\left(\left[\mathrm{ROA}_{t}-\mathrm{ROA}_{t-1}\right]\right)$ controls for residual autocorrelation in changes in ROA not captured by the first partial adjustment term.

To examine whether country-level variables affect mean reversion, we estimate the following variant of model (1):

$$
\begin{array}{r}
\mathrm{ROA}_{\mathrm{i}, \mathrm{t}+1}-\mathrm{ROA}_{\mathrm{i}, \mathrm{t}}=\alpha+\Sigma \kappa \mathrm{CVAR}+\beta\left[\mathrm{ROA}_{\mathrm{i}, \mathrm{t}}-\mathrm{E}\left(\mathrm{ROA}_{\mathrm{i}, \mathrm{t}}\right)\right]+\gamma\left[\mathrm{ROA}_{\mathrm{i}, \mathrm{t}}-\mathrm{ROA}_{\mathrm{i}, \mathrm{t}-1}\right] \\
+\Sigma \delta\left[\mathrm{ROA}_{\mathrm{i}, \mathrm{t}}-\mathrm{E}\left(\mathrm{ROA}_{\mathrm{i}, \mathrm{t}}\right)\right] * \mathrm{CVAR}+\Sigma \varphi\left[\mathrm{ROA}_{\mathrm{i}, \mathrm{t}}-\mathrm{ROA}_{\mathrm{i}, \mathrm{t}-1}\right] * \mathrm{CVAR}
\end{array}
$$

\footnotetext{
${ }^{5}$ The average explanatory power of this model is $20 \%$, similar to the explanatory power that Fama and French (2000) report in their sample of US firms. We also estimated expected ROA by omitting country and industry indicator variables. The predicted ROA was highly correlated $(0.89)$ with the estimate we use. Note, however, that our 12-year sample period is relatively short and may yield noisy lambda estimates.
} 


$$
+\Sigma \lambda \text { Controls }_{\mathrm{i}, \mathrm{t}}+\Sigma \mu \text { Controls }_{\mathrm{i}, \mathrm{t}} * \mathrm{CVAR}+\varepsilon_{\mathrm{i}, \mathrm{t}+\mathrm{1}} .
$$

The interaction term $\delta$ directly tests our main prediction that mean reversion of accounting profits varies systematically with country variables representing product and factor market competition and earnings management (CVAR). The estimated coefficients represent the incremental mean reversion associated with these factors. We cluster standard errors both at the firm and year levels to control for serial correlation in performance persistence within the same firm and for cross-firm correlation within the same year (Petersen 2009). In addition, we adjust the standard errors using the MurphyTopel variance estimator for two-step models (Murphy and Topel 1985). ${ }^{6}$

In addition to the country-level competition variables of primary interest, Model (4) includes controls for firm-, industry-, and country-level variables that prior research has found to be related to mean reversion in profitability (see Cheng 2005 and Nissim and Penman 2001). Firm-level variables include market share, R\&D intensity, the market-to-book multiple, and the level of diversification. Market share (Market Share) is the ratio of a firm's sales to total industry sales, where industries are classified using the Fama-French (1997) four-digit classification. $R \& D$ intensity $(R \& D)$ is $R \& D$ expense deflated by sales. Market-to-book (MTB) controls for future growth opportunities. Industry diversification (Segments) is the number of segments in which a company operates.

Industry-level factors include the industry market-to-book ratio (Industry MTB) as a proxy for the growth prospects of the industry. Following Cheng (2005), we control for

\footnotetext{
${ }^{6}$ The Murphy-Topel adjustment accounts for the fact that estimated regressors (e.g., $\left.\mathrm{E}\left(\mathrm{ROA}_{\mathrm{i}, \mathrm{t}}\right)\right]$ ) may be measured with sampling error. Such sampling error may bias the estimated covariance matrix in the second stage, even in large samples.
} 
industry product innovation using industry $\mathrm{R} \& \mathrm{D}$ intensity (Industry $R \& D$ ), measured as mean R\&D to sales ratio of all firms in the industry. We also include the Herfindahl industry concentration index (Herfindahl), computed by the sum of squared market shares of all firms in an industry, to reflect industry competition (Lev 1983). Prior research indicates that the index is negatively related to industry mean reversion. Also, we include industry indicators to control for other persistent industry-level factors that affect the time-series properties of profits.

Finally, we include country-level controls that reflect the different degrees to which accounting earnings reflect economic fundamentals. Differences in accounting standards and institutional characteristics can lead to differences in how accounting measures of profitability capture economic rate of returns (Rajan, Reichelstein, and Soliman 2007). We control for earnings timeliness measured from an asymmetric timeliness model of earnings and returns as in Bushman and Piotroski (2006). ${ }^{7}$ More timely earnings reflect the faster conversion of economic income into accounting income. Also, we control for the risk of corruption measured as the level of bribery and corruption in each country (Less corruption). We include the level of corruption to control for crosscountry differences in managerial ability to circumvent product, capital, and labor market competition by illegal means (e.g., bribery). ${ }^{8}$ In addition, we include country indicators to

\footnotetext{
${ }^{7}$ Earnings timeliness is the estimated sum of coefficients on stock returns and stock returns times an indicator variable for negative returns, from an asymmetric timeliness model of earnings and returns as in Bushman and Piotroski (2006). We also test the sensitivity of the analysis using measures of timely loss recognition (coefficient on the indicator variable for negative returns) and find similar results.

${ }^{8}$ How the level of corruption will influence the rate of mean reversion in corporate profitability critically depends on who bribes. If more profitable firms pay bribes to acquire permits and contracts, then the rate of mean reversion of corporate profitability will be slower. If less profitable firms pay bribes, then they will be able to improve their performance faster, leading to a faster mean reversion of corporate profitability. Cheung, Rau, and Stouraitis (2012) find that underperforming firms in corrupt countries are more likely to pay bribes, which would accelerate competition and mean reversion in accounting returns. In contrast, Bliss
} 
control for unobserved country-level factors that cause mean reversion of accounting profitability to vary across countries.

\section{Sample and data}

\section{Country-level independent variables}

Annual data on country product and factor market competition are from the IMD World Competitiveness Yearbook (WCY). Each year since 1996, the yearbook has analyzed and ranked the ability of nations to create and maintain an environment that sustains enterprise competitiveness. ${ }^{9}$ It reports more than 300 measures of competitiveness for 58 countries. Approximately two-thirds of the measures reported are statistical data from international, national and regional organizations, private institutions, and a network of 54 partner institutes worldwide. The remaining third are from an annual executive survey (Executive Opinion Survey), which covers such factors as management practices, labor relations, environmental concerns, and quality of life. The number of firms and executives from a given country targeted by the survey is proportional to the country's share of world GDP. Within a country, industries are sampled in proportion to their contribution to the country GDP. Business executives surveyed include nationals and expatriates with global operating experience who are employed by local and foreign enterprises in the country. Survey participants are asked to draw on their experiences to evaluate dimensions of competitiveness for the economy where they have operated and resided during the prior year.

and Di Tella (1997) find that strong performing firms pay bribes to protect their market position, which would reduce mean reversion in accounting returns through less competition.

${ }^{9}$ For more information, see http://www.imd.org/research/publications/wcy/index.cfm 
We use 17 of the variables published by WCY to estimate the country competitiveness variables used in the paper. ${ }^{10}$ The country product market competition variable includes measures of the product market's openness to foreign firms as well as policies, laws and regulations that affect competition in the product market. Country labor market competition includes policies and laws that affect the costs of employment and labor market flexibility. Country capital market competition includes measures of the size and efficiency of banks, stock markets, and other types of financing intermediaries. The specific country-level institutional variables used are defined in the appendix.

To construct country-level variables for product and factor market competition, we first standardize each of the WCY country variables reported in the appendix in a given year by subtracting its mean and dividing by its cross-country standard deviation. This ensures that each variable has equal importance when we aggregate the variables. Next, we generate a single measure of product, capital, and labor market competition for each country-year using the mean of the standardized variables.

Country earnings management variables are computed using the earnings management index from Leuz et al. (2003). The index (EM) is a composite of the wellknown earnings management measures used by prior studies (e.g., smoothing operating earnings through accruals, smoothing reflected in the correlation between changes in operating accruals and operating cash flows, discretionary accruals, and loss avoidance). ${ }^{11}$ Following Leuz et al. (2003) and to mitigate potential measurement error,

\footnotetext{
${ }^{10}$ In untabulated results, we find that the results are largely consistent when we include all 54 parameters in our measure of market competition.

${ }^{11}$ Prior studies find that the small profit measure is a component of the overall measure (Durtschi and Easton 2009). In untabulated analysis, we rerun our analysis excluding the small profit measure from our EM measure. Our inferences remain unchanged.
} 
we construct an overall summary measure of earnings management for each country. For each of the four earnings management measures, countries are ranked such that a higher score suggests a higher level of earnings management. The aggregate earnings management score is computed by averaging the country rankings for the four individual earnings management measures.

\section{Firm and industry variables}

Our data on firm performance are from Worldscope. We restrict our sample to the years 1997 to 2008 . Prior to 1997 , WorldScope has data for only a few developing countries, restricting our ability to investigate the role of country characteristics in performance mean reversion. From the universe of WorldScope, we delete observations with missing data, ROA greater than $100 \%$ or less than $-100 \%$, banks and other financial firms, firms with missing data for consecutive years, firms from countries with no available data in the WCY, and firms from countries with fewer than 50 observations. ${ }^{12}$ We exclude all firms with book value of total assets less than $\$ 5$ million. ${ }^{13}$ The final sample comprises 319,029 firm-year observations for 48,465 unique firms from 49 countries.

Table I presents country means for variables used in the empirical tests. ${ }^{14}$ The country average change in ROA is -0.005 . Hong Kong and Singapore have the most competitive product, labor, and capital markets. Russia and Japan have the least competitive product markets. Slovakia and Mexico have the least competitive capital markets. And France and Germany have the least competitive labor markets. Country

\footnotetext{
${ }^{12}$ Most of the observations we eliminate are for firms classified as financial institutions or firms with missing observations for some of the variables of interest.

${ }^{13}$ Fama and French (2000) exclude the observations of firms with total assets below $\$ 10$ million or a book value of equity below $\$ 5$ million. Given that we have an international sample, we halved the book value of assets threshold. In untabulated analysis, we find that our results are robust to imposing an even lower threshold of $\$ 1$ million.

${ }^{14} \mathrm{We}$ winsorize all dependent and independent variables in the regression at 1 and $99 \%$.
} 
ratings indicate that earnings management is less frequent in the US, Australia and New Zealand, and most severe for Argentina, the Czech Republic, Greece, and Turkey. ${ }^{15}$ The average market share, $\mathrm{R} \& \mathrm{D}$, and MTB across countries are $0.19,1.55 \%$, and 1.85 , respectively. The average Herfindahl index is 0.31 , and the log of number of segments is 0.69 .

Table II presents correlations between the independent variables. Countries with more competitive product and capital markets have firms with higher R\&D and MTB multiples as well as lower market shares, Herfindahl indices, and business diversification. In addition, countries with more competitive product and factor markets show less country-level earnings management and more earnings timeliness (Dhaliwal, et al. 2008). The highest univariate correlation between any of the competition variables is for capital and labor market (0.432), and the lowest correlation is for product and capital market competition (0.350).

\section{Results}

Table III presents the results of estimating model (4). ${ }^{16}$ Because the country-level variables are highly correlated (see Table II), we examine the significance of each variable individually and as a group. Columns (1) and (2) show that the interactive coefficients on the country competition variables are negative and significant, implying that increased product and capital market competition increase the rate of mean reversion

\footnotetext{
${ }^{15} \mathrm{We}$ do not report the country-level competition measures because of the restrictions in the purchase agreement with IMD. Alternatively, we provide the list countries in the high, medium, and low tercile group for each competition measure (see Table I). We thank the editor for making this suggestion.

${ }^{16}$ In untabulated analysis, we find that the country average rate of mean reversion for the pooled sample is 0.26. Fama and French (2000) estimate the mean reversion for a sample of US firms for an earlier period at 0.38 .
} 
as predicted. ${ }^{17}$ These effects are economically and statistically significant. An interquartile increase in product and capital market competition increases the mean reversion of profitability by $9.5 \%$ and $4.2 \%$ respectively. The coefficient on labor market competition in column (3) is insignificant. The coefficient on earnings management in column (4) is negative and significant suggesting that in countries with more earnings management, there is faster mean reversion. However, this coefficient may capture other institutional characteristics correlated with the earnings management proxies.

We therefore include the three market competition variables and the earnings management measures simultaneously in the model. ${ }^{18}$ The results, reported in column (5), show that the interactive product and capital market competition estimates continue to be negative and significant, suggesting that increased competition in these markets is accompanied by higher mean reversion in profitability. An inter-quartile increase in product and capital market competition increases the rate of mean reversion of profitability by $10.9 \%$, and $3.4 \%$ respectively. The estimate on the interactive labor market competition is now positive and significant, indicating that, after controlling for the level of competition in product and capital markets, corporate profitability mean reverts slower in countries with more competitive labor markets. The coefficient on

\footnotetext{
${ }^{17}$ The mean reversion parameters in all these models are negative. A negative interaction term therefore implies that the rate of mean reversion is greater for more competitive countries.

${ }^{18}$ None of the variance inflation factors were higher than four, suggesting that multicollinearity is not a significant problem. We further investigate the stability of the estimated coefficients by estimating our model using a large set of randomly drawn subsamples. We draw 500 samples, each with $50 \%$ of the observations randomly drawn from our original sample. We re-estimate equation (4) and generate a distribution of 500 coefficients for each market competition variable. The sample means (standard deviation) of coefficients on product, capital, and labor market competition are -0.07 (0.022), -0.03 (0.013), and 0.03 (0.014), respectively. The statistical inferences from this analysis resemble those reported in Table III, with t-statistics of 3.18, 2.31, and 2.14 for each of the competitiveness coefficients.
} 
earnings management is insignificant. We investigate these results further in the following section in a nonlinear specification.

To demonstrate how differences in the country variables affect firm performance, we estimate ROA mean reversion for the five countries with the least competitive product markets (lowest decile) and the five countries with the most competitive product markets (top decile). The mean reversion estimates for these subsamples are 0.34 and 0.20 , respectively. Figure Ia shows that firms with extreme positive ROAs of almost 17\% (the top decile) can expect to see their ROA fall to $5 \%$ within four years, if they are domiciled in countries with highly competitive product markets, versus seven years, if they are in the least competitive markets. Similarly, firms with extreme negative ROAs of $-12 \%$ (lowest decile) can anticipate their ROA increasing to $-5 \%$ after three years, if they are in the most competitive product markets, versus five years, if they are in the least competitive markets.

To illustrate how these differences affect firm valuation, consider two hypothetical firms with a weighted average cost of capital of $6 \%$, current ROA of $17 \%$, and book asset growth of $3 \%$. The first firm is from a country in the bottom five competitive product markets where mean reversion is $20 \%$, and the second is from a country in the top five competitive product markets where mean reversion is $34 \%$. We use these estimates to forecast ROA for the next 10 years and generate implied value-toasset multiples for the two firms. ${ }^{19}$ The firm from a top five country has a multiple of

19 The value to book multiples are $\sum_{t=1}^{10} \frac{0.17 *(1-.2)^{\mathrm{t}-1} *(1+g)^{\mathrm{t}-1}}{(1+r)^{\mathrm{t}}}$ for the firm from the bottom five country and $\sum_{t=1}^{10} \frac{0.17 *(1-.34)^{\mathrm{t}-1} *(1+g)^{\mathrm{t}-1}}{(1+r)^{\mathrm{t}}}$ for the firm from the top five country, where $\mathrm{g}$ is the growth rate $3 \%$ and $\mathrm{r}$ is the weighted average cost of capital $6 \%$. 
1.44 versus 1.66 for the firm operating in a bottom five country. For firms with extreme negative ROAs of $-12 \%$, the equivalent value-to-asset ratios are 0.53 and 0.69 .

In Figure $\mathrm{Ib}$, we show the mean reversion pattern using actual (as opposed to predicted) ROA. Here, we use a matched sample to control for other firm characteristics. That is, for each firm in the group of least competitive countries, we find a matching firm from the most competitive countries that is closest in terms of MTB and market share. We control for these two variables because our empirical analyses indicate that they are strong determinants of mean reversion. Similar to Figure Ia, we find that the rate of mean reversion in realized ROA varies systematically by country-level competition. Firms with extreme positive ROAs of $17 \%$ (the top decile) can expect to see their ROA fall to 5\% within five to six years, if they are domiciled in countries with highly competitive product markets, versus almost ten years, if they are in the least competitive markets.

As noted above, model (2) also controls for other firm- and industry-level variables that have been shown to predict performance mean reversion in prior studies. We only present the coefficients of the interaction terms and do not tabulate all the main effects for the sake of parsimony. Consistent with earlier findings, the results in Table III indicate that profitability mean reversion decreases with firm market share, MTB, and diversification and increases with firm R\&D (Cheng 2005), industry MTB (Nissim and Penman 2001), and the Herfindahl index (Jacobsen 1988). The country-level earnings timeliness estimate is positive and weakly significant, indicating that countries with more timely earnings have slower mean reversion (Rajan et al. 2007).

\section{Mean reversion for firms with positive/negative unexpected accounting returns}


We next examine whether the country factors differentially affect mean reversion for firms with positive and negative unexpected accounting returns. The earnings management hypothesis predicts that capital market pressure induces managers of firms with positive unexpected ROAs to manage earnings to slow mean reversion and, for those with negative unexpected ROAs, to accelerate mean reversion. These effects will be intensified in countries with more opportunities for earnings management. We also examine whether the effect of labor market competition documented above for all firms holds equally for firms with positive and negative unexpected ROAs.

To do so, we adopt the approach of Fama and French and expand the partial adjustment model (eq. (4)) and estimate a nonlinear version of the model that differentiates between positive and negative unexpected accounting returns. The nonlinear specification includes all terms as in eq. (4) and interaction terms where each term is interacted with a NEG indicator that takes the value one for firms with negative unexpected ROAs and zero otherwise. Our proxy for unexpected ROA is the difference between realized ROA and expected ROA, where expected ROA is the predicted value of model (2), which is estimated separately on a rolling basis using all prior years in the sample. We estimate the following nonlinear model:

$$
\begin{aligned}
& \mathrm{ROA}_{\mathrm{i}, t+1}-\mathrm{ROA}_{\mathrm{i}, \mathrm{t}}=\alpha+\Sigma \kappa \mathrm{CVAR}+\beta\left[\mathrm{ROA}_{\mathrm{i}, \mathrm{t}}-\mathrm{E}\left(\mathrm{ROA}_{\mathrm{i}, \mathrm{t}}\right)\right]+\gamma\left[\mathrm{ROA}_{\mathrm{i}, \mathrm{t}}-\mathrm{ROA}_{\mathrm{i}, \mathrm{t}-1}\right]+\Sigma \delta\left[\mathrm{ROA}_{\mathrm{i}, \mathrm{t}^{-}}\right. \\
& \left.\left(\mathrm{ROA}_{\mathrm{i}, \mathrm{t}}\right)\right] * \mathrm{CVAR}+\Sigma \varphi\left[\mathrm{ROA}_{\mathrm{i}, \mathrm{t}}-\mathrm{ROA}_{\mathrm{i}, \mathrm{t}-1}\right] * \mathrm{CVAR}+\Sigma \lambda \text { Controls }_{\mathrm{i}, \mathrm{t}}+\Sigma \mu \text { Controls }_{\mathrm{i}, \mathrm{t}} * \mathrm{CVAR}+ \\
& N E G *\left\{\Sigma \kappa_{\text {loss }} C V A R+\beta_{N E G}\left[\operatorname{ROA}_{i, t}-E\left(\operatorname{ROA}_{i, t}\right)\right]+\gamma_{\text {loss }}\left[\operatorname{ROA}_{i, t}-\operatorname{ROA}_{i, t-1}\right]+\Sigma \delta_{N E G}\left[\operatorname{ROA}_{i, t}-E\left(\operatorname{ROA}_{i, t}\right)\right]\right. \\
& \left.* \text { CVAR }+\Sigma \varphi_{\text {loss }}\left[\mathrm{ROA}_{\mathrm{i}, \mathrm{t}}-\mathrm{ROA}_{\mathrm{i}, \mathrm{t}-1}\right] * \mathrm{CVAR}+\Sigma \lambda_{\mathrm{NEG}} \text { Controls }_{\mathrm{i}, \mathrm{t}}+\Sigma \mu_{\mathrm{NEG}} \text { Controls }_{\mathrm{i}, \mathrm{t}} * \mathrm{CVAR}\right\}+\varepsilon_{\mathrm{i}, \mathrm{t}+1} \text {. }
\end{aligned}
$$

The interaction terms, $\delta_{\mathrm{NEG}}$, represent differences in country factors associated with mean reversion for firm-years with positive and negative unexpected accounting returns in the current year t. 
In column (1) of Table IV, we present the results. For observations with positive unexpected ROAs, the product, capital, and labor market estimates are negative and significant, consistent with economic theory—firms in countries with more competitive product, capital, and labor markets experience faster mean reversion in years with positive unexpected ROAs. Consistent with the earnings management hypothesis (Hypothesis 2), the earnings management estimate is 0.0031 and significant, implying slower mean reversion of positive unexpected accounting returns in high earnings management countries. For these firm-years, an inter-quartile increase in earnings management decreases the rate of mean reversion by $3.3 \%$.

For firms with negative unexpected accounting returns, several interesting differences emerge. First, the product market interaction effect is negative and sizable (-0.0944), indicating that mean reversion induced by product market competition is even more pronounced for firms with negative unexpected ROAs. Second, the labor market interaction effect is 0.0817 and significant, indicating that that, when unexpected ROAs are negative, labor market competition slows mean reversion, in contrast to its accelerating effect when unexpected ROAs are positive. One explanation for this finding is that, in competitive labor markets, firms with large negative shocks to ROA find it difficult to retain existing employees and attract new labor required to turn themselves around.

Column (1) also shows that the estimated earnings management coefficient is -0.0084 and significant. This implies that mean reversion of negative unexpected ROAs is faster in countries with a higher propensity for earnings management, consistent with the earnings management hypothesis. The effect is also economically significant-an 
inter-quartile increase in the level of earnings management increases the speed of mean reversion by $5.5 \%$.

In summary, results for firms with positive and negative unexpected accounting returns confirm full sample results that competition in product and capital markets accelerates mean reversion. They also support the hypothesis that capital market incentives to manage earnings to slow or accelerate mean reversion in accounting returns are accentuated in countries where there is a high propensity for earnings management. ${ }^{20}$ The findings provide additional evidence on our earlier findings for country labor market competitiveness by showing that their slowing of mean reversion in accounting returns is driven exclusively by negative unexpected ROA observations.

\section{Additional Tests}

\section{Domestic vs. multinational companies}

The documented country effects should be stronger for domestic firms than for multinationals whose operations are also affected by other countries where they operate. We therefore compare home country competition effects on mean reversion separately for the two types of firms. Domestic firms are defined as those with more than $80 \%$ of

\footnotetext{
${ }^{20}$ Research has indicated that, with more competition in the product markets, firms have less incentive to provide quality disclosure because they have incentives to hide profitable business opportunities from their competitors (Li 2010). This suggests that earnings management incentives to slow mean reversion for highperforming firms and to accelerate mean reversion for poor-performing firms are likely to be attenuated in countries with more competitive product markets. In untabulated results, we test this hypothesis, by estimating the effect of product market competition separately for firm-years with positive and negative unexpected ROAs. The model mirrors equation (5) but includes additional terms that interact the effect of country earnings management and product competition on mean reversion. We find that, for the positive unexpected ROA sub-sample, the significant earnings management estimate of 0.0174 is consistent with managers of countries with a high earnings management propensity using their reporting discretion to delay mean reversion, as documented above. But this effect is attenuated for managers of firms in more competitive product markets, reflected in the significant interactive estimate of -0.0019 . This finding is consistent with product market competition counteracting incentives of managers in countries with high earnings management to boost reported profitability and slow mean reversion.
} 
assets and sales in the home country market, whereas multinational firms have more than $50 \%$ of sales or assets outside their home country. ${ }^{21}$

The first column of Table $\mathrm{V}$ shows that the results for domestic firms are very similar to those reported in Table IV. The second column shows the results for multinational firms. The statistical significance of product market competition, labor market competition, and earnings management are weaker for multinational firms, especially in the presence of losses. Overall, the findings confirm that country effects on ROA mean reversion are lower for multinationals than for purely domestic firms.

Findings using size-weighted variables also support this conclusion. Results using size-weighted variables, where the size weight is sales in US dollars, are shown in column three of Table V. They indicate that home country institutions are less important for the rate of mean reversion for the largest companies in the world. Since these companies operate in dozens of countries, their home country characteristics have less impact on mean reversion in corporate profitability.

\section{Economic development control}

Since institutional forces that drive economic development and market competition are often correlated, our findings for market competition effects could reflect differences in economic development across countries rather than competition per se. To examine this possibility, we estimate the effect of market competition after controlling for the country's level of economic development (GDP per capita). The findings, reported in column four of Table $\mathrm{V}$, show that, after controlling for economic development, most of our results remain qualitatively unchanged. Interestingly, the relation between economic

\footnotetext{
${ }^{21}$ If either foreign assets or sales are missing, then we define a firm as multinational if either foreign assets or sales are greater than $20 \%$ of total assets or sales, respectively.
} 
development and performance mean reversion is positive and significant for firms that report losses, suggesting that controlling for market competition, poor performance in developed economies persists longer than in less developed economies.

\section{One-stage estimation}

Prior studies find that the partial adjustment model can be sensitive to alternative estimation strategies. For example, Flannery and Rangan (2006), in their study of firm leverage, document that the adjustment model estimates are sensitive to the specification of expected leverage, especially when the standard deviation for the first stage estimates are high. They conclude that, when it comes to target leverage, researchers are better off estimating adjustment models in one stage rather than two (Flannery and Rangan 2006, Table 3). Although our estimation does not involve leverage, we examine the sensitivity of our analysis using a one-stage estimation model:

$$
\begin{array}{r}
\mathrm{ROA}_{\mathrm{i}, \mathrm{t}+1}=\alpha+\beta \mathrm{ROA}_{\mathrm{i}, \mathrm{t}}+\gamma \mathrm{ROA}_{\mathrm{i}, \mathrm{t}-1}+\Sigma \kappa \mathrm{CVAR}+\Sigma \lambda \text { Controls }_{\mathrm{i}, \mathrm{t}}+\Sigma \varphi \mathrm{ROA}_{\mathrm{i}, \mathrm{t}-1} * \\
\mathrm{CVAR}+\Sigma \mu \text { Controls }_{\mathrm{i}, \mathrm{t}} * \mathrm{CVAR}+\varepsilon_{\mathrm{i}, \mathrm{t}+\mathrm{l}} .(6)
\end{array}
$$

The Controls $\mathrm{i}_{\mathrm{i}, \mathrm{t}}$ include all the variables used to estimate expected ROA from model (2), in addition to all the existing controls used in model (4).

Table VI reports the estimated results of the nonlinear version of the model that differentiates between abnormal profits and losses. The nonlinear specification includes all terms as in eq. (6) and interaction terms where each term is interacted with a NEG indicator. Coefficients on product, capital, and labor market competition are negative and significant with slightly increased magnitudes compared to the estimates in Table IV. As in Table IV, the country earnings management interaction estimate is positive for firms that outperform expectations and negative for underperformers. 


\section{Out-of sample predictions}

To assess whether the country-level competition and earnings management variables are useful for predicting ROA out of sample, we estimate our basic specification in Table III column (4) with and without the four country-level variables of interest for the years 1997-2002 (first half of our sample). We then use the estimated coefficients to predict the change in ROA in years 2003-2008 under both models (with and without the four country-level variables of interest). We compare the predicted change in ROA with the realized change in ROA and calculate the absolute difference between the two (forecast error). In untabulated analyses, we find statistically significant reductions in the mean (value $=-0.0028, \mathrm{p}$-value $=0.0486)$ and median $($ value $=-0.0012, \mathrm{p}$ value $=0.0822$ ) forecast errors using the model that includes the four country variables. These findings lead us to conclude that adding the four country variables improves the ability to forecast ROA out-of-sample.

\section{Conclusion}

This paper tests whether persistence in firms' accounting returns varies systematically across countries. We find that country product, capital, and labor market (although the effect of labor market is not robust across all specifications) competition all affect the rate of mean reversion of corporate profitability. When we consider all variables simultaneously, we find that product market and capital market variables have the largest impact on performance persistence. Labor market competitiveness appears to increase mean reversion for firm-years when ROAs exceed expectations, consistent with economic theory. But it slows mean reversion in poor performance years. We argue that 
underperforming firms in countries with competitive labor markets have difficulty retaining and attracting talented employees to implement a turnaround. However, we recognize that other country-level characteristics might be correlated with labor market competition and cause this effect on mean reversion. Finally, in countries with higher earnings management propensity, profitability mean reverts slower for firms with positive unexpected ROAs and faster for those with negative unexpected accounting returns, consistent with capital market incentives driving earnings management.

Our study is subject to several caveats. First, as with any empirical study, the findings are a joint test of the empirical proxies correctly capturing the managerial intent. This is particularly relevant for our earnings management tests. Although there is a large literature using the measure employed in our tests in an international context, it may be confounded by other institutional characteristics we examine, leading to an errors-invariables problem (Durtschi and Easton 2009, Wysocki 2009). Second, although our predictions are supported by economic theory and are robust to various controls and specifications, we recognize that it is difficult to prove causality, especially given various alternative channels that drive competitive forces in the economy (e.g., government regulation).

Notwithstanding such limitations, we believe that our findings are likely to be useful to scholars and practitioners interested in understanding how country factors affect corporate profitability. At a practical level, our results indicate that valuation exercises, which require terminal value assumptions on the sustainability of profitability, can benefit from considering country as well as traditional firm and industry factors in settling on the speed with which superior or inferior profits are likely to mean revert. 
Also, including the country-level competition measures is likely to improve the predictive ability of future corporate profitability.

Our study raises several questions for future research. For example, we considered home-country characteristics that could affect mean reversion of profitability across the world. Yet the sustainability of multinational firms' profitability is also likely to be influenced by host-country competitive and efficiency factors (Rodríguez et al. 2005). Future research could also examine whether research analysts understand and incorporate the implications of differences in country product and factor competition and earnings management in their long-term forecasts. 


\section{References}

Aghion, P., Harris, C., Howitt, P., and J. Vickers, 2001. Competition , Imitation and Growth with Step-by-Step Innovation, Review of Economic Studies 68(3): 467-492.

Aghion, P., 2002. Schumpeterian Growth Theory and the Dynamics of Income Inequality.

Arrow, K. J., and G. Debreu, 1954. The existence of an equilibrium for a competitive economy. Econometrica, 22(3): 265-290.

Ball, R., Kothari, S.P., and A. Robin. 2000. The effect of institutional factors on properties of accounting earnings. Journal of Accounting and Economics 29(1): 1-51.

Beaver, W. H. 1970. The Time Series Behavior of Earnings. Empirical Research in Accounting: Selected Studies. Supplement to Journal of Accounting Research: 62-89.

Bliss, C., and R. Di Tella, 1997. Does Competition Kill Corruption?, Journal of Political Economy 105(5):1001-24.

Botero, J., S. Djankov, R. La Porta, F. Lopez-de-Silanes, and A. Shleifer, 2004. The regulation of labor, Quarterly Journal of Economics 119: 1339-1382.

Bushman R. and J., Piotroski, 2006. Financial reporting incentives for conservative accounting: The influence of legal and political institutions, Journal of Accounting and Economics 42: 107-48.

Caves, R., 1989. International differences in industrial organization. In R. Schmalensse, \& R.W. Willig (Ed.) Handbook of Industrial Organization: 1225-1246. Amsterdam: North-Holland.

Cheng, Q., 2005. What determines residual income? The Accounting Review 80: 85-112.

Cheung Y., P. R. Rau, and A. Stouraitis, 2012. How much do firms pay as bribes and what benefits do they get? Evidence from corruption cases worldwide," NBER Working Papers 17981.

Dechow, P., D. Skinner. 2000. Earnings Management: Reconciling the Views of Accounting Academics, Practitioners, and Regulators. Accounting Horizons 14: 235-250.

Dhaliwal D., Huang, S., Khurana I., and R., Pereira 2008. Product Market Competition and Accounting Conservatism. Working paper.

Doidge, C., G. Karolyi, A., and R. Stulz, 2007. Why do countries matter so much for corporate governance? Journal of Financial Economics 86: 1-39.

Durtschi, C. and P. Easton, 2009. Earnings Management? Erroneous Inferences Based on Earnings Frequency Distributions, Journal of Accounting Research 47(5):1249-1281. 
Fairfield, P.J., Ramnath, S., and T. Yohn, 2009. Do industry-level analyses improve forecast of financial performance? Journal of Accounting Research 47 (1): 147-178.

Fama, E.F., and K.R French, 1997. Industry costs of equity. Journal of Financial Economics 43 (2): 158-193.

Fama, E.F., and K.R. French, 2000. Forecasting profitability and earnings. Journal of Business 73: 161-175.

Fama, E.F, and K.R. French, 2006. Profitability, investment and average returns. Journal of Financial Economics 82: 491-518.

Flannery, M., and K.P., Rangan, 2006. Partial adjustment toward target capital structures. Journal of Financial Economics 79: 469-506.

Francis, J., R. LaFond, P., Olsson and K., Schipper 2004. Costs of Equity and Earnings Attributes, The Accounting Review 79 (4): 967-1010.

Freeman, R., 1988. Labor market institutions and economic performance, Economic Policy 3(1): 63-80.

Freeman, R., Ohlson J., Penman, A., and H., Stephen, 1982. Book Rate-of-Return and Prediction of Earnings Changes: An Empirical Investigation. Journal of Accounting Research 20(2): 639-653.

Healy, P. M., K. G. Palepu, and V. L. Bernard. Business Analysis and Valuation. 2nd ed. Southwestern Publishing Company, 2000.

Healy, P., and J. Wahlen. 1999. A Review of the Earnings Management Literature and Its Implications for Standard Setting. Accounting Horizons 365-383.

Hoskisson, R.E. Eden L. Lau, C., and M. Wright, 2000. Strategy in emerging economies. Academy of Management Journal 43(3): 249-267.

Jacobsen, R., 1988. The Persistence of Abnormal Returns. Strategic Management Journal 9: 415-430.

Khanna, T., and K.G. Palepu, 1997. Why focused strategies may be wrong in emerging markets. Harvard Business Review 75(4): 41-51.

Kothari, S.P., 2001. Capital market research in accounting, Journal of Accounting and Economics 31: 105-231.

La Porta, R., Lopez-de-Silanes, F., Shleifer, A. and R. Vishny, 1998. Law and finance. Journal of Political Economy 106: 1113-1155.

Leuz, C. Nanda, D. and P. Wysocki, 2003. Earnings management and investor protection: An international comparison. Journal of Financial Economics 69: 505-527.

Lev, B. 1983. Some economic determinants of time-series properties of earnings. Journal of Accounting and Economics 5: 31-48. 
Lippman, S. A. and R. P. Rumelt, 1982. Uncertain Imitability: An analysis of interfirm differences in efficiency under competition. Bell Journal of Economics 13: 418-438.

$\mathrm{Li}, \mathrm{X} ., 2010$, The impact of product market competition on the quantity and quality of voluntary disclosures, Review of Accounting Studies 15(3): 663-711.

Murphy, K. M. and R. H. Topel. 1985. Estimation and inference in two-step econometric models. Journal of Business and Economic Statistics 3(4): 370-379.

Morck, R., Wolfenzon, D., and B. Yeung, 2005. Corporate governance, economic entrenchment and growth. Journal of Economic Literature 63: 655-720.

Nissim, D. and S. Penman, 2001. Ratio analysis and equity valuation: From research to practice. Review of Accounting Studies 6: 109-54.

North, D. 1990. Institutions, institutional change and economic performance. New York: Cambridge University.

Ohlson, J. 1995. Earnings, book values and dividends in equity valuation. Contemporary Accounting Research 11: 661-687.

Penman, S., 1991. An Evaluation of the Accounting Rate of Return. Journal of Accounting, Auditing and Finance: 233-256.

Penman, S., 2006. Handling valuation models. Journal of Applied Corporate Finance 18(2): 48-55.

Penman, S., X. Zhang, 2002. Accounting conservatism, the quality of earnings, and stock returns. The Accounting Review 77(2): 237-274.

Petersen, M.A. 2009. Estimating Standard Errors in Finance Panel Data Sets: Comparing Approaches, Review of Financial Studies 22(1): 435-80.

Porter, M.E. 1980. Competitive Strategy: Techniques for Analyzing Industries and Competitors. New York: Free Press.

Porter, M.E. 1985. The Competitive Advantage: Creating and Sustaining Superior Performance. New York: Free Press.

Porter, M.E. 1990. The competitive advantage of nations. New York: Free Press.

Rajan, M., S. Reichelstein and M. Soliman. 2007. Conservatism, Growth, and Return on Investment, Review of Accounting Studies 12: 325-370.

Rodríguez, P., Uhlenbruck, K., and L. Eden, 2005. Government corruption and the entry strategies of multinationals. Academy of Management Review 30(2): 383-396.

Schumpeter, J. 1942. Capitalism, Socialism and Democracy. Harper and Brothers, New York 3rd edition. 
Siegel, J., I., and B.Z. Larson, 2009. Labor Market Institutions and Global Strategic Adaptation: Evidence from Lincoln Electric. Management Science 55(7): 1527-1546.

Stigler, G. 1961. The Economics of Information, Journal of Political Economy 69:213225.

Waring, G.F., 1996. Industry Differences in the Persistence of Firm-Specific Returns. The American Economic Review 86(5):1253-1265.

Wiggins, R. R. and T.W. Ruefli, 2002. Sustained competitive advantage: Temporal dynamics and the incidence and persistence of superior economic performance. Organization Science 13(1): 81-105.

Wurgler, Jeffrey., 2000. Financial markets and the allocation of capital. Journal of Financial Economics 58:187-214.

Wysocki, P. 2009. Assessing earnings and accruals quality: U.S. and international evidence. Working paper. 


\section{Appendix}

\section{Selected Measures from IMD World Competitiveness Yearbook used to Construct Annual Country Product and Factor Market Competition Variables}

\begin{tabular}{|c|c|}
\hline \multicolumn{2}{|l|}{ Product market competition } \\
\hline Protectionism & Protectionism does not impair the conduct of your business \\
\hline Public sector contracts & Public sector contracts are sufficiently open to foreign bidders \\
\hline Subsidies & Subsidies do not distort fair competition and economic development \\
\hline Ease of doing business & Ease of doing business is supported by regulations \\
\hline Creation of firms & Creation of firms is supported by legislation \\
\hline \multicolumn{2}{|l|}{ Labor market competition } \\
\hline Labor regulations & Labor regulations do not hinder business activities \\
\hline Unemployment legislation & Unemployment legislation provides an incentive to look for work \\
\hline Immigration laws & Immigration laws do not prevent your company from employing foreign labor \\
\hline Redundancy costs & Number of weeks of salary \\
\hline Labor market flexibility & Index on rigidity of employment (index 0-100) \\
\hline \multicolumn{2}{|l|}{ Capital market competition } \\
\hline Banking sector assets & Percentage of GDP \\
\hline Banking and financial services & Banking and financial services do support business activities efficiently \\
\hline Financial institutions' transparency & Financial institutions' transparency is sufficiently implemented \\
\hline Stock market capitalization & Percentage of GDP \\
\hline Shareholders' rights & Shareholders' rights are sufficiently implemented \\
\hline Venture capital & Venture capital is easily available for businesses \\
\hline \multicolumn{2}{|c|}{$\begin{array}{l}\text { The IMD Institute uses the following methodology to provide a ranking of the competitiveness of each nation: Each sub-variabl } \\
\text { that is a survey item takes a value from } 1 \text { to } 10 \text {. All other sub-variables that are hard measures take their raw values. All sub } \\
\text { variables are then standardized across countries by subtracting the average across the countries and dividing by the standar } \\
\text { deviation. Then the standardized values of the sub-variables are aggregated. For more information see: } \\
\text { http://www.imd.org/research/publications/wcy/upload/methodology.pdf }\end{array}$} \\
\hline
\end{tabular}


Figure I: Evolution of estimated ROA for firms from countries with the least and most competitive product markets

Figure Ia

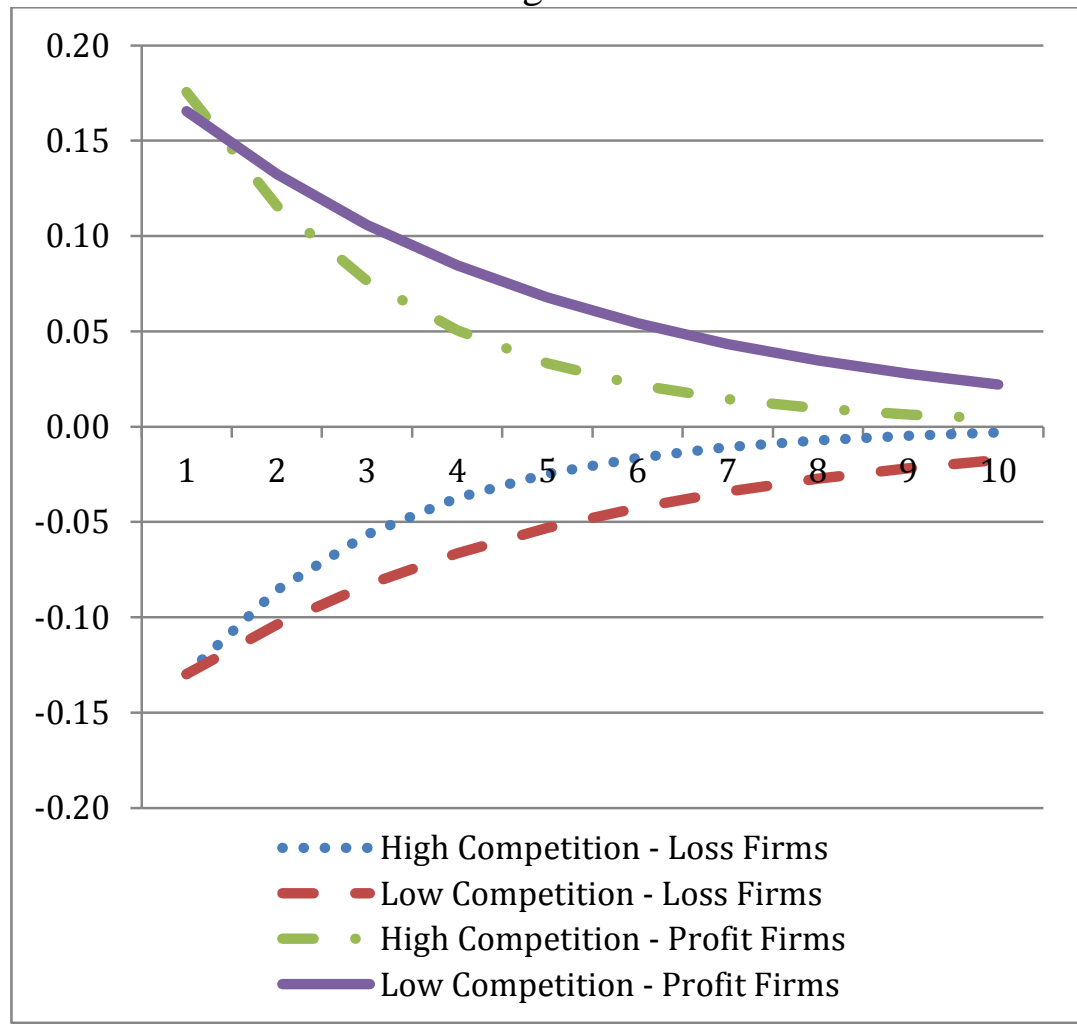

Figure $\mathrm{Ib}$

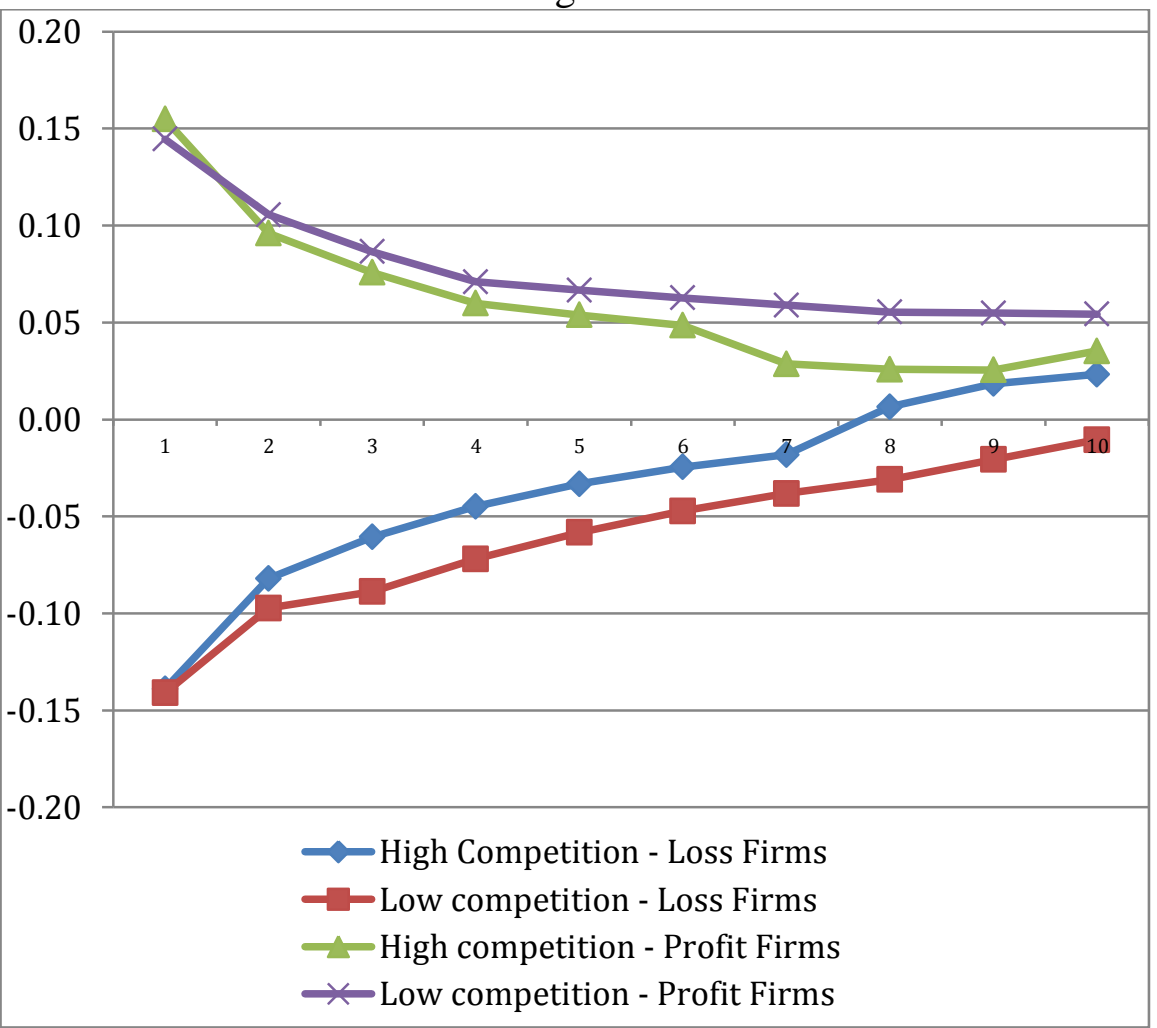

Figure I shows the evolution of estimated ROA for two groups of countries: for the five countries with the least competitive product markets and for the five countries with the most competitive product markets across the years in the sample. Figure Ia is based on the coefficients from the predicted values from a multivariate regression. The estimated mean reversion for the sample of countries with the most (least) competitive product markets is 0.35 ( 0.24$)$. The beginning ROA is equal to the ROA of a firm that ranks on the $90^{\text {th }}$ percentile or the $10^{\text {th }}$ percentile of the ROA distribution. Figure Ib is based on the mean actual ROA for the firms in each sub-sample over the five subsequent years. To ensure that our results are not driven by differences in firm characteristics, we match for each firm in the group of least competitive countries with a firm from the most competitive countries that is closest in terms of market to book value and market share. 
Table I: Summary statistics by country

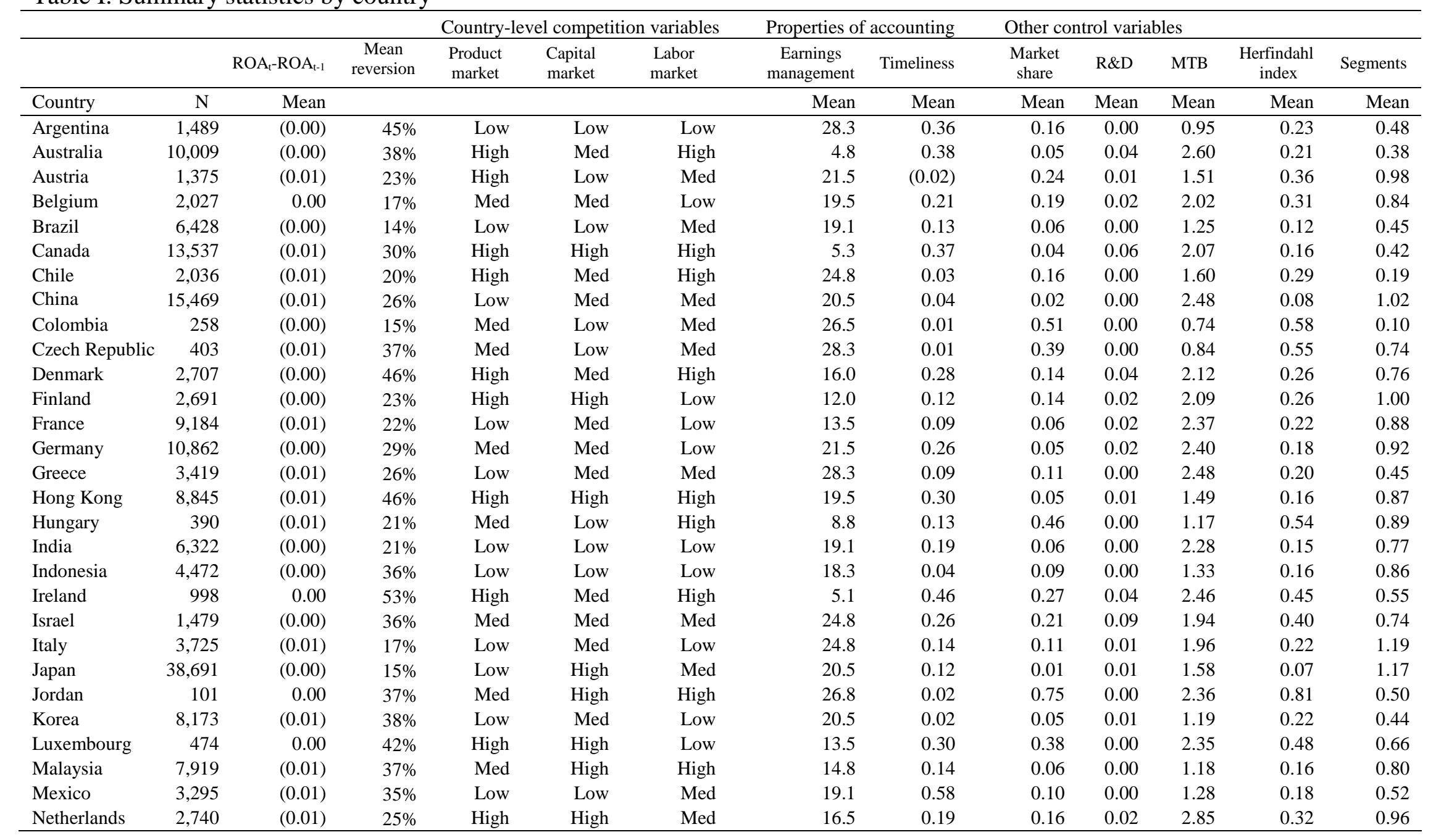


Table I: Summary statistics by country (Continued)

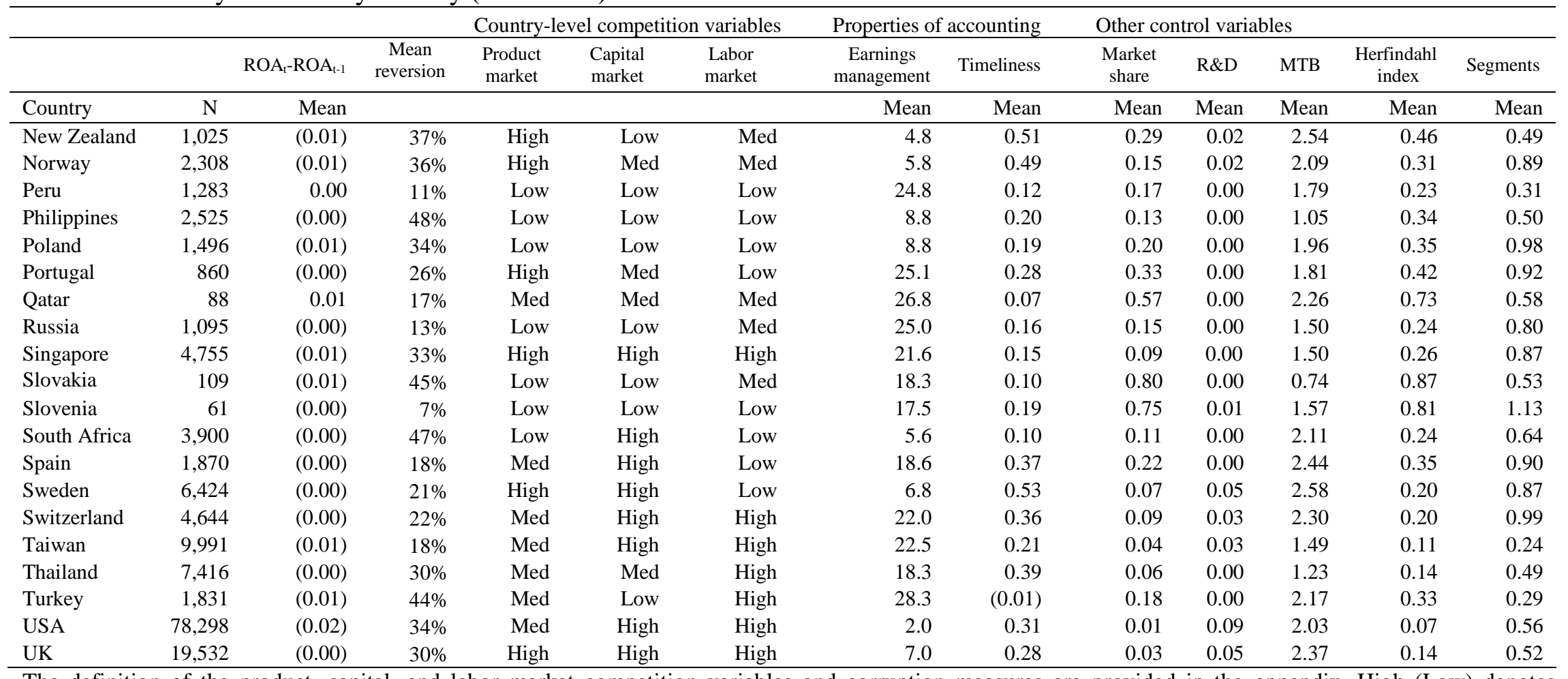

The definition of the product, capital, and labor market competition variables and corruption measures are provided in the appendix. High (Low) denotes countries with competition variables in the highest (lowest) tercile and Med in the medium terciles. Earnings management is the country average rank across all four measures (two earnings smoothness and two earnings discretion measures) calculated as in Leuz, Nanda, and Wysocki (2003). Timeliness is the estimated sum of coefficients on stock returns and stock returns times an indicator variable for negative returns, from an asymmetric timeliness model of earnings and returns as in Bushman and Piotroski (2006). Market share is firm sales over sum of sales of all firms classified in the same Fama-French (1997) industry and country-year. R\&D is research and development expenses over sales. MTB is market value of equity at fiscal year-end over book value of equity. Industry MTB is the average MTB of all firms included in a Fama-French (1997) industry and country-year. Industry R\&D is the average R\&D of all firms included in a FamaFrench (1997) industry and country-year. Herfindahl is the sum of squared market shares across companies for each industry-country-year. Segments is the natural logarithm of the number of four-digit SIC codes that the firm operates in. 
Table II: Correlation matrix

\begin{tabular}{|c|c|c|c|c|c|c|c|c|c|c|c|c|}
\hline \multirow{3}{*}{ Variable } & \multirow{3}{*}{$\begin{array}{l}\text { Market } \\
\text { share } \\
\text { (1) }\end{array}$} & \multirow{3}{*}{$\begin{array}{c}R \& D \\
(2)\end{array}$} & \multirow{3}{*}{$\begin{array}{c}\text { MTB } \\
(3)\end{array}$} & \multirow{3}{*}{$\begin{array}{l}\text { Industry } \\
\text { MTB } \\
(4)\end{array}$} & \multirow{3}{*}{$\begin{array}{l}\text { Industry } \\
\text { R\&D } \\
(5)\end{array}$} & \multirow{3}{*}{$\begin{array}{l}\text { Herfindahl } \\
\text { index } \\
(6)\end{array}$} & \multirow{3}{*}{\multicolumn{2}{|c|}{$\begin{array}{cc}\begin{array}{c}\text { Product } \\
\text { market }\end{array} \\
\text { Segments competition } \\
\text { (7) }\end{array}$}} & \multirow{3}{*}{$\begin{array}{l}\text { Capital } \\
\text { market } \\
\text { competition } \\
\text { (9) }\end{array}$} & \multirow{3}{*}{$\begin{array}{c}\text { Labor } \\
\text { market } \\
\text { competitior } \\
\text { (10) }\end{array}$} & \multirow{3}{*}{$\begin{array}{c}\text { Less } \\
\text { ncorruption } \\
\quad(11)\end{array}$} & \multirow{3}{*}{$\begin{array}{c}\text { Earnings } \\
\text { Management } \\
\text { (12) }\end{array}$} \\
\hline & & & & & & & & & & & & \\
\hline & & & & & & & & & & & & \\
\hline (1) & 1.000 & & & & & & & & & & & \\
\hline (2) & -0.069 & 1.000 & & & & & & & & & & \\
\hline (3) & 0.009 & 0.060 & 1.000 & & & & & & & & & \\
\hline (4) & 0.049 & 0.110 & 0.269 & 1.000 & & & & & & & & \\
\hline (5) & -0.107 & 0.510 & 0.076 & 0.216 & 1.000 & & & & & & & \\
\hline (6) & 0.630 & -0.035 & 0.010 & 0.082 & -0.072 & 1.000 & & & & & & \\
\hline (7) & 0.100 & -0.121 & 0.006 & -0.027 & -0.149 & -0.036 & 1.000 & & & & & \\
\hline (8) & 0.054 & 0.070 & 0.048 & 0.145 & 0.143 & 0.095 & -0.140 & 1.000 & & & & \\
\hline (9) & -0.059 & 0.002 & 0.025 & 0.038 & 0.010 & -0.080 & 0.025 & 0.350 & 1.000 & & & \\
\hline (10) & -0.151 & 0.099 & -0.010 & -0.048 & 0.205 & -0.223 & -0.092 & 0.409 & 0.432 & 1.000 & & \\
\hline (11) & -0.067 & 0.126 & 0.042 & 0.093 & 0.249 & -0.010 & -0.035 & 0.617 & 0.397 & 0.320 & 1.000 & \\
\hline (12) & 0.160 & -0.197 & -0.039 & -0.112 & -0.393 & 0.158 & 0.181 & -0.364 & -0.043 & -0.380 & -0.510 & 1.000 \\
\hline Timeliness & -0.032 & 0.123 & 0.028 & 0.084 & 0.242 & -0.012 & -0.161 & 0.476 & 0.156 & 0.249 & 0.512 & -0.579 \\
\hline
\end{tabular}

Table II presents Pearson correlation coefficients. Market share is firm sales over sum of sales of all firms classified in the same Fama-French (1997) industry and country-year. R\&D is research and development expenses over sales. MTB is market value of equity at fiscal year-end over book value of equity. Industry MTB is the average MTB of all firms included in a Fama-French (1997) industry and country-year. Industry R\&D is the average R\&D of all firms included in a Fama-French (1997) industry and country-year. Herfindahl is the sum of squared market shares across companies for each industry-country-year. Segments is the natural logarithm of the number of four-digit SIC codes that the firm operates in. Less corruption is a measure of the lack of bribery and corruption in a country from the IMD World Competitiveness Yearbook. Earnings management is the country average rank across all four measures (two earnings smoothness and two earnings discretion measures) calculated as in Leuz, Nanda, and Wysocki (2003). Timeliness is the estimated sum of coefficients on stock returns and stock returns times an indicator variable for negative returns, from an asymmetric timeliness model of earnings and returns as in Bushman and Piotroski (2006). All other variables are defined in the appendix. The definition of the product, capital, and labor market competition variables are provided in the appendix. 
Table III: Relation between persistence in accounting profitability and country-level competition

\begin{tabular}{|c|c|c|c|c|c|c|c|c|c|c|}
\hline \multirow[b]{2}{*}{ Parameter } & \multicolumn{2}{|c|}{ (1) } & \multicolumn{2}{|c|}{ (2) } & \multicolumn{2}{|c|}{ (3) } & \multicolumn{2}{|c|}{ (4) } & \multicolumn{2}{|c|}{ (5) } \\
\hline & Estimate & $\mathrm{t}$ & Estimate & $\mathrm{t}$ & Estimate & $\mathrm{t}$ & Estimate & $\mathrm{t}$ & Estimate & $\mathrm{t}$ \\
\hline Intercept & -0.0420 & -20.14 & -0.0482 & -25.32 & -0.0316 & -15.14 & -0.0709 & -30.58 & -0.0596 & -21.02 \\
\hline (ROAt-Et(ROA)) & 0.0853 & 2.49 & -0.1023 & -4.06 & -0.2103 & -7.47 & -0.1320 & -4.83 & 0.0040 & 0.10 \\
\hline$($ ROAt-Et(ROA))*Market share & 0.4041 & 9.20 & 0.3773 & 8.65 & 0.3828 & 8.64 & 0.3696 & 8.44 & 0.3965 & 8.97 \\
\hline$(\mathrm{ROAt}-\mathrm{Et}(\mathrm{ROA}))^{*} \mathrm{R} \& \mathrm{D}$ & -0.0553 & -2.13 & -0.0517 & -1.99 & -0.0522 & -2.01 & -0.0591 & -2.28 & -0.0634 & -2.44 \\
\hline$(\mathrm{ROAt}-\mathrm{Et}(\mathrm{ROA}))^{*} \mathrm{MTB}$ & -0.0053 & -5.95 & -0.0052 & -5.82 & -0.0052 & -5.79 & -0.0051 & -5.67 & -0.0052 & -5.80 \\
\hline$($ ROAt-Et(ROA))*Industry MTB & -0.0222 & -6.17 & -0.0241 & -6.60 & -0.0243 & -6.66 & -0.0257 & -6.96 & -0.0178 & -4.90 \\
\hline$(\mathrm{ROAt}-\mathrm{Et}(\mathrm{ROA}))^{*}$ Industry R\&D & 0.2327 & 3.89 & 0.2513 & 4.19 & 0.2470 & 4.08 & 0.2306 & 3.73 & 0.1777 & 2.87 \\
\hline$(\mathrm{ROAt}-\mathrm{Et}(\mathrm{ROA}))^{*}$ Herfindahl & -0.2429 & -5.78 & -0.2650 & -6.26 & -0.2381 & -5.48 & -0.2167 & -5.04 & -0.1889 & -4.35 \\
\hline$(\mathrm{ROAt}-\mathrm{Et}(\mathrm{ROA})) *$ Segments & -0.0025 & -0.31 & 0.0058 & 0.72 & 0.0036 & 0.45 & 0.0094 & 1.16 & 0.0057 & 0.70 \\
\hline$($ ROAt-Et(ROA $))^{*}$ Less corruption & 0.0070 & 1.94 & -0.0068 & -2.06 & -0.0148 & -4.69 & -0.0147 & -4.54 & 0.0128 & 3.23 \\
\hline$($ ROAt-Et(ROA $))^{*}$ Earnings timeliness & 0.1418 & 2.96 & 0.0334 & 0.71 & 0.0619 & 1.29 & -0.0119 & -0.23 & 0.1038 & 1.99 \\
\hline$($ ROAt-Et $($ ROA $)) *$ Product market competition & -0.0658 & -9.86 & & & & & & & -0.0747 & -10.00 \\
\hline$($ ROAt-Et(ROA))*Capital market competition & & & -0.0290 & -5.14 & & & & & -0.0234 & -3.49 \\
\hline$($ ROAt-Et(ROA))*Labor market competition & & & & & 0.0067 & 1.73 & & & 0.0304 & 6.43 \\
\hline$(\operatorname{ROAt}-\mathrm{Et}(\mathrm{ROA})) *$ Earnings management & & & & & & & -0.0027 & -3.39 & 0.0009 & 1.08 \\
\hline Adj. R-squared & $15.29 \%$ & & $14.99 \%$ & & $14.75 \%$ & & $14.81 \%$ & & $15.98 \%$ & \\
\hline $\mathrm{N}$ & 319,029 & & 319,029 & & 319,029 & & 319,029 & & 319,029 & \\
\hline
\end{tabular}

Dependent variable is the change in return on assets between year $t$ and $t+1$. The unit of analysis is the firm-year. Market share is firm sales over sum of sales of all firms classified in the same Fama-French (1997) industry and country-year. R\&D is research and development expenses over sales. MTB is market value of equity at fiscal year-end over book value of equity. Industry MTB is the average MTB of all firms included in a Fama-French (1997) industry and country-year. Industry R\&D is the average R\&D of all firms included in a Fama-French (1997) industry and country-year. Herfindahl is the sum of squared market shares across companies for each industry-country-year. Segments is the natural logarithm of the number of four-digit SIC codes that the firm operates in. Less corruption is a measure of the lack of bribery and corruption in a country from the IMD World Competitiveness Yearbook. Earnings management is the country average rank across all four measures (two earnings smoothness and two earnings discretion measures) calculated as in Leuz, Nanda, and Wysocki (2003). Timeliness is the estimated sum of coefficients on stock returns and stock returns times an indicator variable for negative returns, from an asymmetric timeliness model of earnings and returns as in Bushman and Piotroski (2006). All other variables are defined in the appendix. All variables are included as main effects but only the interactions are presented for parsimony. The lag change in ROA and all interaction terms between lag change in ROA and other variables are also included but not reported in the table. Standard errors are robust to heteroscedasticity and (i) clustered at the firm and year level and (ii) adjusted using the Murphy-Topel variance estimator for two-step models (Murphy and Topel 1985). 
Table IV Relation between performance persistence and earnings management, by positive and negative unexpected profitability

\begin{tabular}{|c|c|c|c|c|c|c|c|c|c|c|}
\hline \multirow[b]{2}{*}{ Parameter } & \multicolumn{2}{|c|}{$\begin{array}{c}(1) \\
\text { All firm-years }\end{array}$} & \multicolumn{2}{|c|}{$\begin{array}{c}(2) \\
\text { Domestic firms }\end{array}$} & \multicolumn{2}{|c|}{$\begin{array}{c}\text { (3) } \\
\text { Multinationals }\end{array}$} & \multicolumn{2}{|c|}{$\begin{array}{c}(4) \\
\text { Value-weighted }\end{array}$} & \multicolumn{2}{|c|}{$\begin{array}{c}\text { (5) } \\
\text { Control for } \\
\text { economic } \\
\text { development }\end{array}$} \\
\hline & Coef. & $\mathrm{t}$ & Coef. & $\mathrm{t}$ & Coef. & $\mathrm{t}$ & Coef. & $\mathrm{t}$ & Coef. & $\mathrm{t}$ \\
\hline Intercept & -0.0319 & -10.96 & -0.04 & -8.83 & -0.01 & -1.16 & -0.02 & -1.94 & -0.01 & -3.85 \\
\hline$($ ROAt-Et(ROA)) & -0.1088 & -2.70 & -0.19 & -3.73 & -0.19 & -1.96 & -0.17 & -3.19 & -0.28 & -5.06 \\
\hline$($ ROAt-Et(ROA))*Product market competition & -0.0173 & -2.33 & -0.01 & -1.46 & -0.03 & -1.28 & -0.01 & -1.93 & 0.00 & 0.13 \\
\hline$($ ROAt-Et(ROA))*Capital market competition & -0.0249 & -3.43 & -0.02 & -2.02 & -0.04 & -2.51 & -0.02 & -1.58 & -0.03 & -3.97 \\
\hline$($ ROAt-Et(ROA))*Labor market competition & -0.0159 & -3.10 & -0.01 & -1.56 & -0.02 & -1.05 & 0.00 & 0.25 & 0.00 & -0.76 \\
\hline$($ ROAt-Et(ROA))*Earnings management & 0.0031 & 3.47 & 0.05 & 0.77 & 0.64 & 3.41 & -0.02 & -0.12 & 0.11 & 2.01 \\
\hline$($ ROAt-Et(ROA))*Economic development & & & & & & & & & -0.01 & -1.10 \\
\hline $\mathrm{Neg} *($ ROAt-Et $(\mathrm{ROA})) *$ Product market competition & -0.0944 & -6.16 & -0.10 & -5.83 & -0.01 & -0.15 & -0.01 & -0.38 & -0.12 & -7.62 \\
\hline Neg*(ROAt-Et(ROA $)) *$ Capital market competition & 0.0042 & 0.29 & 0.01 & 0.43 & 0.03 & 0.97 & -0.02 & -0.50 & 0.01 & 0.85 \\
\hline Neg*(ROAt-Et(ROA))*Labor market competition & 0.0817 & 8.00 & 0.09 & 7.09 & 0.02 & 0.60 & -0.03 & -1.64 & 0.05 & 4.54 \\
\hline Neg*(ROAt-Et(ROA) $) *$ Earnings management & -0.0084 & -4.66 & 0.28 & 1.92 & -1.22 & -3.47 & 0.03 & 0.18 & 0.02 & 0.15 \\
\hline Neg*(ROAt-Et(ROA))*Economic development & & & & & & & & & 0.13 & 6.30 \\
\hline Firm, industry and country-level controls (Table III) & & Yes & & Yes & & Yes & & Yes & & Yes \\
\hline$($ ROAt-Et(ROA))* Control variables & & Yes & & Yes & & Yes & & Yes & & Yes \\
\hline Adj. R-squared & & $16.54 \%$ & & $17.41 \%$ & & $13.08 \%$ & & $14.87 \%$ & & $16.61 \%$ \\
\hline $\mathrm{N}$ & & 319,029 & & 238,409 & & 32,694 & & 319,029 & & 319,029 \\
\hline
\end{tabular}


Table V Robustness test - one stage estimation

\begin{tabular}{|c|c|c|}
\hline Parameter & Estimate & $\mathrm{t}$ \\
\hline Intercept & -0.1654 & -8.85 \\
\hline ROAt & 0.7996 & 22.10 \\
\hline ROAt*Market share & 0.1569 & 2.41 \\
\hline ROAt*R\&D & -0.4390 & -3.40 \\
\hline ROAt*MTB & 0.0132 & 5.81 \\
\hline ROAt*Industry MTB & -0.0043 & -0.66 \\
\hline ROAt*Industry R\&D & 0.2576 & 1.45 \\
\hline ROAt*Herfindahl & -0.1931 & -3.05 \\
\hline ROAt*Segments & -0.0136 & -1.07 \\
\hline ROAt*Dividends & -0.0207 & -0.53 \\
\hline ROAt*Dividend Indicator & 0.2476 & 13.68 \\
\hline ROAt*Size & 0.0332 & 8.50 \\
\hline ROAt*Leverage & -0.3771 & -10.61 \\
\hline ROAt*Less corruption & 0.0075 & 1.15 \\
\hline ROAt*Earnings Timeliness & -0.3618 & -4.47 \\
\hline ROAt*Product market competition & -0.0715 & -5.87 \\
\hline ROAt*Capital market competition & -0.0204 & -1.93 \\
\hline ROAt*Labor market competition & -0.0414 & -5.00 \\
\hline ROAt*Earnings Management & 0.0049 & 3.21 \\
\hline Neg*ROAt*Market share & -0.3233 & -3.34 \\
\hline Neg*ROAt*R\&D & 0.3518 & 2.63 \\
\hline Neg*ROAt*MTB & -0.0145 & -5.79 \\
\hline Neg*ROAt*Industry MTB & -0.0096 & -1.22 \\
\hline Neg*ROAt*Industry R\&D & -0.0277 & -0.14 \\
\hline Neg*ROAt*Herfindahl & 0.1653 & 2.15 \\
\hline Neg*ROAt*Segments & -0.0489 & -3.00 \\
\hline Neg*ROAt*Dividends & 0.0700 & 0.87 \\
\hline Neg*ROAt*Dividend Indicator & -0.5186 & -16.20 \\
\hline Neg*ROAt*Size & -0.0543 & -12.56 \\
\hline Neg*ROAt*Leverage & 0.2443 & 6.23 \\
\hline Neg*ROAt*Less corruption & 0.0131 & 1.56 \\
\hline Neg*ROAt*Earnings Timeliness & 0.5933 & 5.29 \\
\hline Neg*ROAt*Product market competition & -0.0483 & -3.34 \\
\hline Neg*ROAt*Capital market competition & -0.0240 & -1.78 \\
\hline Neg*ROAt*Labor market competition & 0.0726 & 7.39 \\
\hline Neg*ROAt*Earnings Management & -0.0083 & -2.45 \\
\hline Adj. R-squared & $53.2 \%$ & \\
\hline $\mathrm{N}$ & 319,029 & \\
\hline
\end{tabular}

Dependent variable is the change in return on asset between year $t$ and $t+1$. The unit of analysis is the firm-year. $\mathrm{Neg}$ is an indicator that takes the value one for firms with negative unexpected ROAs and zero otherwise. We proxy for unexpected ROA by taking the difference of the realized ROA and the expected ROA, estimated as the predicted value from the model using equation (2). Market share is firm sales over sum of sales of all firms classified in the same Fama-French (1997) industry and country-year. R\&D is research and development expenses over sales. MTB is market value of equity at fiscal year-end over book value of equity. Industry MTB is the average MTB of all firms included in a Fama-French (1997) industry and country-year. Industry R\&D is the average R\&D of all firms included in a Fama-French (1997) industry and country-year. Herfindahl is the sum of squared market shares across companies for each industry-country-year. Segments is the natural logarithm of the number of four-digit SIC codes that the firm operates in. Dividends is dividends over book value of equity. Dividend indicator is an indicator variable that takes a value of one for firms that pay dividend and zero otherwise. Size is the natural logarithm of sales. Leverage is total debt over total assets. Earnings management is the country average rank across all four measures (two earnings smoothness and two earnings discretion measures) calculated as in Leuz, Nanda and Wysocki (2003). Timeliness is the estimated sum of coefficients on stock returns and stock returns times an indicator variable for negative returns, from an asymmetric timeliness model of earnings and returns as in Bushman and Piotroski (2006). Less corruption is a measure of the lack of bribery and corruption in a 
country from the IMD World Competitiveness Yearbook. All other variables are defined in the appendix. All variables are included as main effects but only the interactions are presented for parsimony. The lag change in ROA and all interaction terms between lag change in ROA and other variables are also included but not reported in the table. Standard errors are robust to heteroscedasticity and clustered at the firm and year level. 